Vol. 25, No. 1, Januari - Juni 2018
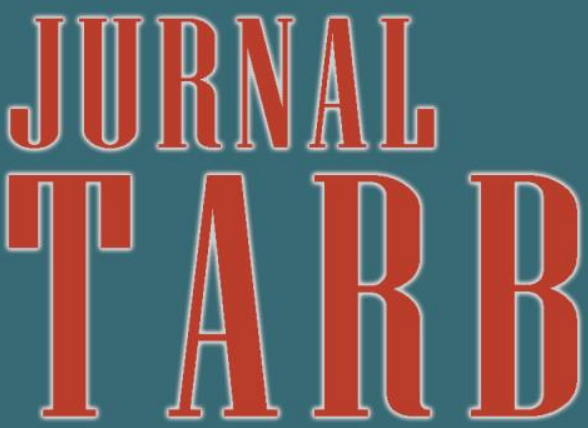
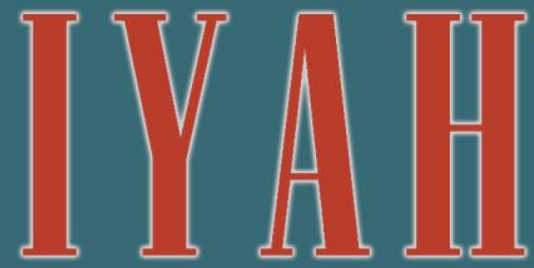

ETIKA AKADEMIS DALAM PENDIDIKAN ISLAM

POLA PEMBINAAN KEAGAMAAN DI SMA PLUS BOARDING SCHOOL ASTHA HANNAS SUBANG

POLA PENGAJARAN KESANTUNAN BERBAHASA ANAK DI LINGKUNGAN KELUARGA

SEKULARITAS DAN SPRITUALITAS: MENCARI FORMAT INTEGRASI ILMU UNTUK KONSTRUKSI KURIKULUM PENDIDIKAN ISLAM

MENINGKATKAN HASIL BELAJAR IPA DENGAN METODE EKSPERIMEN

PENERAPAN STRATEGI INDEX CARD MATCH UNTUK MENINGKATKAN HASIL BELAJAR SISWA PADA MATA PELAJARAN BAHASA INDONESIA

PENINGKATAN HASIL BELAJAR MATEMATIKA SISWA MELALUI STRATEGI PAKEM DI KELAS VIII MTS NURUL AMALIYAH TANJUNG MORAWA

PENANAMAN KONSEP ILMU KEGURUAN DAN PEMBENTUKAN KARAKTER CALON GURU BAHASA INDONESIA FKIP UNIVERSITAS MUHAMMADIYAH SUMATERA UTARA BERBASIS RUMPUN MODEL SOSIAL

WAWASAN AL-QUR'AN TENTANG METODE PENDIDIKAN

THE EFFECT OF USING SOCIAL MEDIA ON THE STUDENTS' VOCABULARY ACHIEVEMENT AT TENTH GRADE STUDENTS OF SMA SWASTA PERSIAPAN STABAT ACADEMIC YEAR 2017/2018 


\title{
JURNAL TARBIYAH
}

Terbit dua kali dalam setahun, edisi Januari - Juni dan Juli - Desember. Berisi tulisan atau artikel ilmiah ilmu-ilmu ketarbiyahan, kependidikan dan keislaman baik berupa telaah, konseptual, hasil penelitian, telaah buku dan biografi tokoh

\section{Penanggung Jawab}

Dekan Fakultas Ilmu Tarbiyah dan Keguruan UIN Sumatera Utara Medan

\section{Ketua Penyunting}

Mesiono

\author{
Penyunting Pelaksana \\ Junaidi Arsyad \\ Sakholid Nasution \\ Eka Susanti \\ Sholihatul Hamidah Daulay
}

\section{Penyunting Ahli}

Firman (Universitas Negeri Padang, Padang)

Naf'an Tarihoran (Institut Agama Islam Negeri Sultan Maulana Hasanuddin, Banten) Jamal (Universitas Negeri Bengkulu, Bengkulu)

Hasan Asari (Universitas Islam Negeri Sumatera Utara, Medan)

Fachruddin Azmi (Universitas Islam Negeri Sumatera Utara, Medan)

Ibnu Hajar (Universitas Negeri Medan, Medan)

Khairil Ansyari (Universitas Negeri Medan, Medan)

Saiful Anwar (Institut Agama Islam Negeri Raden Intan, Lampung)

\section{Desain Grafis}

Suendri

\section{Sekretariat}

Maryati Salmiah

Reflina

Nurlaili

Ahmad Syukri Sitorus 


\title{
POLA PEMBINAAN KEAGAMAAN DI SMA PLUS BOARDING SCHOOL ASTHA HANNAS SUBANG
}

\author{
Haris Munandar \\ Mahasiswa Pendidikan Agama Islam SPs UPI Bandung \\ Email: hmunandarg9@yahoo.co.id \\ DOI : $10.30829 /$ tar.v25i1.233 \\ Diterima : 10 Januari 2018 \\ Diterbitkan : 31 Maret 2018
}

\begin{abstract}
Abstrak: Pendidikan agama diajarkan di sekolah - sekolah di Indonesia. Salah satunya SMA Plus Boarding School Astha Hannas. Adapun permasalahan yang diangkat dari penelitian ini adalah (1) Apa yang dimaksud boarding school ? (2) Nilai-nilai keagamaan apa yang ingin dicapai di SMA Plus boarding school Astha Hannas ? (3) Bagaimana strategi yang digunakan SMA tersebut dalam menanamkan nilai-nilai keagamaan pada siswanya? (4) bagaimana hasil dari penyelenggaraan pembinaan kegamaan siswa di SMA Plus Boarding School Astha Hannas?. Adapun teknik pengumpulan datanya dengan menggunakan wawancara, observasi serta dokumentasi. Setelah data dilapangan didapatkan kemudian dianalisis dan dibahas sehingga menghasilkan penjabaran yang faktual tentang Model Pembinaan Keagamaan Boarding School.
\end{abstract}

Kata Kunci: pembinaan keagamaan, boarding school

Abstract : Religious education is taught in Indonesian school. One of them is in SMA Plus Boarding School Astha Hannas. The problems raised from this research are (1) what is boarding school? (2) what religious values do you want to achieve in SMA Plus boarding school Astha Hannas? (3) How is the strategy used by the high school in instilling religious values in the students? (4) how is the result of the implementation of coaching students in SMA Plus Boarding School Astha Hannas ?. The data collection techniques used interviews, observation and documentation. After the field data got obtained then analyzed and discussed so as to produce factual explanation about Religious Boarding School Development Model.

Keywords: religious guidance, boarding school 


\section{Pendahuluan}

Seorang anak dilahirkan ibunya dalam suatu kondisi yang lemah dan tidak tahu apapun namun ia diberikan potensi dalam dirinya yang perlu dibina oleh orang tua hingga ia dewasa. Seorang anak pun menjadi amanah dari Allah swt yang harus disayangi dengan sepenuh hati dan dirawat sebaik mungkin, selain itu anak juga berperan sebagai generasi penerus agama, keluarga, ras dan bangsa yang harus diwarisi nilai-nilai generasi tersebut.

Ditinjau dari sisi psikologisnya menurut Ihsan dan Hasan (1998:117) manusia disebut homodivinous (makhluk yang percaya adanya Tuhan) atau disebut juga homoreligious artinya makhluk yang beragama. Alasan manusia mampu beragama atau percaya akan adanya Tuhan adalah karena di dalam jiwa manusia terdapat insting religious atau garizaђ diniyaђ. Insting ini tidak akan berkembang secara baik apabila pendidikan keagamaan tidak diberikan secara berkesinambungan dan harmonis, oleh karena itu pendidikan keagamaan perlu ditanamkan dari mulai usia dini.

Hal yang patutnya terjadi apabila anak bangsa ini sudah mengenyam pendidikan agama dari Taman Kanak-Kanan sampai dengan Sekolah Menengah Atas (SMA) maka hasilnya Bangsa ini akan menjadi aman dan tentram, namun kenyataannya sekarang ini walaupun ilmu pengetahuan dan teknologi mengalami kemajuan tetapi sebaliknya nilainilai keagamaan yang dijunjung negara ini dirasa semakin hilang. Hal ini terbukti dengan beberapa kasus yang terjadi pada lembaga-lembaga pemerintahan maupun swasta yang ada di Indonesia seperti kasus korupsi, kolusi dan nepotisme, selain itu pada generasi penerus bangsa terjadi tawuran antar pelajar, minuman keras, mencontek dan perilaku indisipliner lainnya.

Di sinilah sistem pendidikan di Indonesia perlu menekankan pentingnya pendidikan karakter peserta didik yang berakhlak dan bermoral sesuai dengan nilai agama dan norma yang berlaku di masyarakat yang menjadi pedoman dasar kehidupan bermasyarakat dan bernegara. Selain itu penting pula menerapkan pendidikan agama hususnya agama Islam dalam proses pendidikan di Indonesia dalam menumbuhkembangkan akidah dan akhlak melalui pemupukan dan pengembangan pengetahuan, penghayatan dan pengamalan peserta didik tentang agama Islam.

Kehadiran salah satu lembaga pendidikan pada jenjang Sekolah Menengah Atas (SMA) dan bersistem boarding school dapat dikatakan sebagai salah satu langkah untuk mengurangi kenakalan remaja dan kasus-kasus yang terjadi di masa sekarang ini sekaligus merespon atas kebutuhan masyarakat atau orang tau kakrir yang mempunyai kesibukan dalam kesehariannya. Untuk itu dalam rangka menghasilkan individu yang 
berkualitas dalam hal pengetahuan umum dan keagamaan, berakhlak mulia, menjaga kesatuan dan persatuan NKRI dan mampu bersaing dalam seleksi masuk Perguruan Tinggi Negri, TNI, POLRI dan dunia kerja lainnya, maka SMA Plus Astha Hannas membuat lingkungan sekolah bersistem boarding school yang di dalamnya mempunyai pola pembinaan dengan disiplin tinggi yang dirancang secara sistematis.

Pesantren merupakan salah satu lembaga pendidikan yang mengajarkan ilmu agama. Sehingga dipilih pesantren sebagai lokasi penelitian.

Hasil penelitian ini diharapkan dapat memberikan kontribusi terhadap kekayaan keilmuan yang terus berkembang dalam dunia pendidikan, khususnya mengenai pola pembinaan keagamaan siswa pada lingkungan boarding school pada jenjang Sekolah Menengah Atas (SMA) maupun untuk jenjang sekolah lainnya.

\section{Metode}

Studi ini menggunkan metode penelitian deskriptif (descriptive researche), yaitu suatu metode penelitian yang secara garis besar dilakukan untuk memperoleh gambaran mengenai keadaan yang terjadi pada masa sekarang. Sebagaimana Syaodih (2010:72) menjelaskan bahwa penelitian deskriptif adalah suatu bentuk penelitian yang paling dasar. Ditujukan untuk mendeskripsikan atau menggambarkan fenomena-fenomena yang ada, baik fenomena yang bersifat alamiah ataupun rekayasa manusia. Penelitian ini mengkaji bentuk aktivitas, karakteristik, perubahan, hubungan, kesamaan dan perbedaannya dengan fenomena lain. Dalam karya ilmiah ini penulis memakai pendekatan kualitatif, Bodgan dan Tylor (Zuriah, 2006:92) bahwa penelitian kualitatif adalah prosedur penelitian yang menghasilkan data deskriptif berupa kata-kata tertulis atau lisan dari orang-orang dan perilaku yang dapat diamati.

Penelitian kualitatif ini dipilih karena penelitian ini meneliti tentang pola pendidikan di Pesantren Asta Annas, teknik dan metode penelitian kualitatif ini dianggap dapat memberikan jawaban atas pertanyaan - pertanyaan pada penelitian ini.

Dalam mengumpulkan data dari tempat penelitian, peneliti menggunakan observasi langsung, wawancara dan studi dokumentasi. Penelitian ini dilakukan di SMA Plus Boarding School Astha Hannas Subang yang beralamatkan di jalan Raya Binong No. 64, Binong Kabupaten Subang Jawa Barat. Pemilihan lokasi penelitian ini didasari karena SMA Plus Boarding School Astha Hannas merupakan sekolah yang menerapkan kurikulum diknas dan kurikulum khas Astha Hannas yang mana out put dari perpaduan kurikulum tersebut terbukti menghasilkan siswa yang berbeda dengan sekolah lain. 
Informan penelitian terdiri dari tenaga pendidik, siswa dan orang tua siswa. setelah data hasil observasi, dokumentasi dan wawancara, selanjutnya data yang diperoleh diolah menjadi beberapa uraian-uraian singkat dan padat lalu disimpulkan dengan berdasarkan bukti-bukti yang valid dan konsisten.

\section{Hasil dan Pembahasan}

\section{Boarding School}

Boarding School terdiri dari dua kata yaitu boarding dan school. Boarding berarti asrama dan school berarti sekolah. Menurut Zahra (2008 :145) boarding school adalah sistem sekolah dengan asrama, dimana peserta didik dan juga para guru dan pengelola sekolah tinggal di asrama yang berada dalam lingkungan sekolah dalam kurun waktu tertentu biasanya satu semester diselingi dengan berlibur satu bulan sampai menamatkan sekolahnya. Sedangkan Maksudin (2006:8) mendefinisikan bahwa boarding school adalah sekolah yang memiliki asrama, dimana para siswa hidup ; belajar secara total di lingkungan sekolah. Karena itu segala jenis kebutuhan hidup dan kebutuhan belajar disediakan oleh sekolah.

Dari definisi di atas dapat disimpulkan bahwa boarding school adalah sekolah yang memiliki asrama, dimana dalam asrama tersebut siswa tinggal bersama dengan pendidik dalam kurun waktu tertentu dan disediakan berbagai kebutuhan sehari-hari serta fasilitas penunjang ketercapaian pendidikan.

Sesungguhnya term boarding school bukan sesuatu yang baru dalam konteks pendidikan di Indonesia karena sudah sejak lama lembaga-lembaga pendidikan di Indonesia menghadirkan konsep pendidikan boarding school yang diberi nama "pondok pesantren" pondok pesantren ini adalah cikal bakal boarding school di Indonesia. Akan tetapi pondok pesantren zaman dahulu difokuskan kepada penanaman nilai-nilai agama dan nilai-nilai yang berlaku di masyarakat dengan tanpa kurikulum yang tertulis. Hal ini yang menjadi salah satu perbaikan pendidikan pesantren dan sekaligus menghasilkan model sistem pendidikan boarding school.

Sekolah berasrama (boarding school) dengan kurikulumnya yang terpadu memiliki program dan kegiatan intrakulikuler, kokulikuler maupun ekstrakulikuler yang terstrukutur dan integratif guna terciptanya keserasian dan keseimbangan dalam meraih visi dan misi sekolah.

Di lingkungan sekolah, setiap harinya siswa dapat melakukan interaksi dengan siswa lain dari mulai bangun sampai tidur, bahkan bukan hanya interaksi dengan siswa saja melainkan dengan guru pun bisa berinteraksi dengan leluasa namun tetap ada sikap 
menghargai kepada guru ang dilakukan oleh siswa. sehingga dari interaksi yang leluasa ini guru bisa lebih leluasa mentransferkan ilmu, mencontohkan sikap dan melatih keterampilan kepada siswanya. Oleh karena itu, munculnya sekolah berasrama sekarang ini telah menggantikan posisi dan peran pendidikan keluarga dalam upaya meningkatkan keberagamaan siswa, sikap kedisiplinan, pengetahuan dan sebagainya. Sehingga sangatlah wajar boarding school menjadi pilihan masyarakat hususnya orang tua karir di masa sekarang.

Di dalam boarding school kegiatan dijadwalkan mulai dari bangun pagi sampai menjelang tidur. Pada pagi hari siswa berangkat ke sekolah tanpa harus memakai kendaraan, hanya cukup dengan berjalan kaki karena jarak antara asrama dengan kelas tempat belajar siswa sangatlah dekat. Begitupun dengan tempat ibadah, yaitu masjid. Masjid bagi siswa boarding school yang memeluk agama Islam merupakan tempat yang nyaman untuk mengerjakan salat dan mengaji. Selain itu Masjid menjadi salah satu pusat pembinaan yang efektif, bukan hanya nilai-nilai keagamaan saja melainkan juga pembinaan kedidiplinan, kecerdasan emosional dan lain sebagainya.

Selain lingkungan yang nyaman dan kegiatan terarah yang menjadi penentu keberhasilan tujuan pendidikan boarding school, strategi dan metodologi pun menjadi faktor penunjang keberhasilan pendidikan di boarding school. Strategi yang dipakai di lingkungan boarding school dikaitkan dengan kurikulum, tokoh dan juga metodologi. Samani dan Hariyanto (2016:144) mengutarakan bahwa dalam kaitannya dengan kurikulum, strategi yang umum dilaksanakan adalah mengintegrasikan pendidikan karakter dalam bahan ajar. Artinya, tidak membuat kurikulum pendidikan karakter sendiri. Strategi terkait dengan adanya model tokoh yang sering dilakukan di negaranegara maju adalah bahwa seluruh tenaga pendidik dan tenaga kependidikan (Kepala Sekolah, seluruh guru, dan seluruh tenaga Bimbingan dan Konseling serta seluruh tenaga administrasi di sekolah harus mampu menjadi model teladan yang baik (uswaђ ḥasanaђ).

\section{Tujuan Pembinaan Keagamaan}

Dari hasil wawancara dengan kepala sekolah dan guru - guru maka didapatkan hasil: SMA Plus boarding School Astha Hannas merupakan sekolah yang kental akan kemiliterennya dan hampir seluruh tenaga pelatih juga pengasuhnya adalah pensiunan dan yang masih aktif di TNI dan POLRI. Sekolah bertaraf nasional yang digagas oleh Prof. DR. Ermaya Suradinata, SH., MH., MS dan berkiprah dengan menanamkan semangat jiwa dan raga untuk membentuk kepribadian yang unggul dalam rangka pembangunan bangsa ini, sejak awal keberadaanya dirancang sebagai tempat pendidikan dan pelatihan 
untuk membangun karakter bangsa bagi para calon pemimpin yang berwawasan kebangsaan.

Sekolah ini mempunyai misi yang salah satunya adalah menanamkan nilai-nilai keagamaan. Adapun tujuan penanaman nilai-nilai keagamaan yang ingin dicapai di SMA Plus boarding School Astha Hannas Subang adalah:

a. Iman

iman yaitu sikap batin yang penuh kepercayaan kepada Allah swt bahwa Ia hanya ada satu dan melihat segala sesuatu yang dilakukan manusia serta mengabulkan permohonan hamba-Nya yang meminta. Selain itu orang yang beriman akan mempunyai perasaan gembira apabila melakukan kebaikan dan resah apabila melakukan suatu keburukan.

b. Takwa

Takwa yaitu sikap yang timbul dalam diri untuk berbuat sesuatu yang diridhai Allah dengan melaksanakan segala yang diperintahkan-Nya dan menjaga diri dari segala sesuatu yang dilarang-Nya.

c. Disiplin

Disiplin adalah kepatuhan untuk menghormati dan melaksanakan suatu sistem yang mengharuskan orang untuk tunduk kepada keputusan, perintah dan peraturan yang berlaku.

d. Peduli

Kepedulian berarti memerhatikan atau menaruh perhatian terhadap sesuatu. Dalam bahasa Arab kepedulian disebut "al-ri'āyałatau al-hassās, yaitu memerhatikan atau peka terhadap sekitarnya. Jadi sikap peduli ini lebih pada sikap membantu menyelesaikan permasalahan yang dihadapi orang lain dengan tujuan kebaikan individu atau bersama.

\section{Strategi Pembinaan Keagamaaan}

Secara umum SMA Plus Boarding School Astha Hannas merupakan suatu sistem yang sifatnya terpadu. Muhaimin (2009:104) menjelaskan bahwa sekolah terpadu berarti memadukan sekolah dan pesantren. Sekolah terpadu bersinkronisasi dengan kebijakan pendidikan nasional sehingga terbiasa dengan perubahan-perubahan dan inovasi. Masuknya pesantren ke dalam sekolah berarti bukan hanya bertugas memelihara dan meneruskan tradisi yang berlaku di Pesantren, tetapi juga mengembangkan pola-pola budaya baru agar bisa membantu peserta didik dan masyarakat untuk mengakomodasi perubahan yang sedang dan sudah terjadi. Bahkan mampu mengembangkan pola-pola pelatihan dan pendidikan "baru" guna menjawab tuntutan perubahan perubahan dari 
zaman ke zaman. Peserta didik di sekolah terpadu diposisikan sebagi siswa sekaligus santri. Guru atau pendidiknya pun diposisikan dan dikondisikan sebagai ustaz atau ustazaђ .

Dengan begitu bisa diketahui bahwa boarding school adalah sekolah berasrama yang menerapkan beberapa sistem yang ada di pesantren dan sistem sekolah umum pada lingkungan sekolahnya seperti penerapan sistem dalam membina aqidah, ilmu pengetahuan dan juga keterampilan yang unggul.

Melihat kondisi masyarakat Indonesia sekarang yang makin merosot akhlaknya, maka perlu ada pendidikan yang sifatnya terpadu, harmonis dan berkesinambungan sampai akhir hayat. Asyafah (2016:39) menjelaskan bahwa upaya pendidikan memang jangkauannya luas, karena pendidikan tidak hanya bersifat mengajar dalam arti hanya menyampaikan ilmu pengetahuan kepada peserta didik, melainkan -dan ini yang lebih penting- membina atau mengembangkan kepribadian peserta didik itu, baik di dalam kelas maupun di luar kelas, bai yang sifatnya kurikuler maupun non kurikuler. Seluruh aspek kejiwaan (kognitif, afektif dan psikomotor) harus berkembang secara padu, harmonis dan seimbang. Penekanan hanya pada salah satu aspek saja berarti tidak mendidik manusia secara kaffaђ (sempurna), dan akan mengakibatkan disharmoni yang akan menimbulkan perilaku yang merugikan dirinya dan juga masyarakatnya.

SMA Plus Boarding School Astha Hannas mempunyai misi yang salah satunya adalah menanamkan nilai-nilai keagamaan. Dalam menanamkan nilai-nilai keagamaan, SMA Plus Boarding School Astha Hannas memakai pola yang terpadu, dinamis dan berkesinambungan pada tiga kurikulum khasnya yaitu pengajaran, pelatihan dan pengasuhan (tri tunggal) dengan mengacu pada pola: pertama, dilandaskan kepada iman kepada Allah swt. Artinya segala perbuatan yang dilakukan setiap hari dari mulai bangun tidur, belajar dan berlatih sampai tidur kembali harus ada nama Allāh di dalamnya agar perbuatan itu bernilai ibadah. Kedua, lingkungan dengan suasana militer yang penuh dengan kedisiplinan, kerapihan dan ketegasan. Ketiga, membiasakan kegiatan keagamaan dalam aktivitas sehari-hari di lingungan sekolah. Keempat, pemberian teladan oleh ketua yayasan, kepala sekolah, pengajar, pelatih, pengasuh dan tenaga kependidikan pada siswa. kelima, pemberian hukuman bagi siswa yang melanggar aturan dan hadiah bagi siswa yang berprestasi di bidang pengajaran, pelatihan dan pengasuhan.

Adapun tiga sistem kurikulum yang menjadi ciri khas SMA Plus boarding School Astha Hannas Subang adalah sebagai berikut: 


\section{Pengajaran}

Pengajaran tetap mengikuti kurikulum nasional dan telah mempergunakan kurikulum tahun 2013 dengan mata pelajaran pendidikan agama (Islam/Kristen), pendidikan kewarganegaraan, bahasa dan sastra Indonesia, sejarah Indonesia, bahasa Inggris, matematika, pendidikan jasmani dan kesehatan, seni budaya, prakarya dan kewirausahaan, bahasa Jerman, bahasa Arab dan dengan muatan lokal bahasa Sunda juga PLH. Untuk peminatan MIA (IPA) pelajarannya adalah matematika, fisika, kimia dan biologi. Sedangkan peminatan SOS (IPS) mata pelajarannya adalah sejarah, geografi, sosiologi dan ekonomi. Dalam pengajaran, setiap awal masuk kelas guru memimpin siswa untuk berdo'a, mengajak siswa untuk salat berjamaah apabila waktu salat duhur dan ashar tiba dan menutup KBM dengan berdo'a pula. Adapun untuk pembelajaran PAI setelah berdo'a dibiasakan untuk membaca al-asmā al-ḥusna dan membaaca ayat-ayat pilihan sesuai dengan materi yang akan dipelajari. Adapun waktu pengajaran dimulai dari pukul 07.00 sampai dengan pukul 15.00, apabila tiba waktunya salat maka pembelajaran diberhentikan sejenak untuk melaksanakan salat berjamaah.

2. Pelatihan

Kurikulum pelatihan SMA Plus Boarding School Astha Hannas merupakan pedoman dasar dalam satu kesatuan penyelenggaraan kegiatan pendidikan dan menjadi landasan dalam menggunakan ilmu pengetahuan, penerapan praktek dan etika pemerintahan di lingkungan SMA Plus boarding School Astha Hannas. Pelatihan diberikan kepada peserta didik dengan tujuan memberikan soft skill agar siswa mempunyai keterampilan berbahasa, berolahraga, berseni, dan teknologi. Adapun kurikulum pelatihannya yaitu sepak bola, futsal, voli, basket, bahasa Inggris, bahasa Jerman, bahasa Arab, seni budaya dan teknologi informatika dan komunikasi (TIK). Dalam pelaksanaan pelatihan agar tertanam nilai-nilai keagamaan, pelatih yang terdiri dari pengajar mata pelajaran membiasakan membaca do'a ketika sebelum dan setelah berlatih dan juga untuk pelatihan bahasa pelaksanaannya dilakukan di Masjid Sekolah yaitu Masjid An-Nās. Untuk peserta yang belajar, pelatih tidak menghususkan untuk agama Islam saja melainkan seluruh siswa yang bergama selain Islam, seluruh siswa yang mempunyai bahasa tertentu saja atau siswa suku tertentu saja. Misalkan ada orang Papua yang beragama selain Islam boleh mengikuti pelatihan bahasa Arab danpelataihanpelatihan lainnya. adapun waktu pelatihan dimulai dari pukul 15.30 sampai dengan 16.00 WIB. 


\section{Pengasuhan}

Pengasuhan merupakan suatu sarana atau alat yang tidak berbentuk dan berwujud namun di dalamnya terdapat proses hubungan secara sadar dan terencana yang digunakan untuk menyampaikan pesan nilai-nilai dari orang dewasa kepada orang yang belum dewasa. Pengasuhan di SMA Plus boarding School Astha Hannas diarahkan pada upaya untuk membentuk kepribadian peserta didik sebagai manusia yang beriman dan bertakwa kepada Tuhan Yang Maha Esa dan memiliki karakter yang unggul. Adanya kurikulum pengasuhan di SMA Plus boarding School Astha Hannas ini didasari oleh keyakinan bahwa apabila siswa hanya belajar di kelas saja maka siswa akan banyak kekurangannya, sehingga nilai-nilai agama dan nilai-nilai sosial yang ada pada masyarakat juga nilai-nilai persatuan-dan kesatuan Negara Republik Indonesia tidak dimiliki oleh siswa sebagai generasi penerus agama, suku dan bangsa. Adapun waktu pengasuhan lebih banyak daripada pengajaran dan pelatihan, yaitu waktu di mana tidak berlangsungnya KBM dan pelatihan. Pengasuh siswa adalah orang yang selalu menemani siswa ketika makan, salat dan kegiatan selain KBM dan pelatihan, selain itu pengasuh juga menjadi orang yang memantau ketika siswa beraktivitas di sekolah dan ketika siswa beristirahat di malam hari juga membangunkan siswa untuk melaksanakan salat subuh.

Berbicara mengenai ketiga sistem kurikulum khas SMA Plus Boarding School Astha Hannas, tentunya hal itu merupakan upaya baik yang dilakukan pendidik, pelatih dan pengasuh. Upaya mencapai tujuan pendidikan tentunya bukan hanya mengajarkan aspek pengetahuan dan keterampilan yang diberikan pada waktu yang sudah ditetapkan oleh sekolah saja melainkan perlu ada tindakan lain di luar waktu yang sudah ditentukan yang sifatnya penting untuk menunjang ketercapaian tujuan pendidikan. Asyafah (2016, hal.39) menjelaskan bahwa upaya pendidikan memang jangkauannya luas, karena pendidikan tidak hanya bersifat mengajar dalam arti hanya menyampaikan ilmu pengetahuan kepada peserta didik, melainkan -dan ini yang lebih penting- membina atau mengembangkan kepribadian peserta didik itu, baik di dalam kelas maupun di luar kelas, baik yang sifatnya kurikuler maupun non kurikuler. Seluruh aspek kejiwaan (kognitif, afektif dan psikomotor) harus berkembang secara padu, harmonis dan seimbang. Penekanan hanya pada salah satu aspek saja berarti tidak mendidik manusia secara kaffaђ (sempurna), dan akan mengakibatkan disharmoni yang akan menimbulkan perilaku yang merugikan dirinya dan juga masyarakatnya.

Upaya ketiga sistem kurikulum khas SMA Plus Boarding School Astha Hannas dalam mencapai tujuan pendidikan khususnya pembinaan agama ditunjang oleh beberapa metode, yaitu: keteladanan pengajar, pelatih dan pengasuh, pembiasaan dzikir 
dan berdo'a setelah salat, pembiasaan membaca ayat suci Al-Qur`ān, pemberian nasihat oleh siswa lain dan pengajar melalui tausyiah dan melalui khutbah jum'at serta pemberian hukuman dan hadiah.

Selain kurikulum khas tersbut yang dipakai untuk membina nilai-nilai keagamaan siswa, SMA Plus Boarding School Astha Hannas juga memakai metode yang pas di lingkungan sekolah untuk membina nilai-nilai keagamaan pada siswanya. Adapun metode yang dipakai adalah:

a. Keteladanan

Pada abad 21 ini seorang pendidik dituntut untuk mengajarkan kecerdasan intelektual (IQ), kecerdasan emosional (EQ) dan kecerdasan spiritual (SQ) karena apabila dimensi-dimensi tersebut tidak tersentuh oleh seorang pendidik maka siswa tidak akan mempunyai hidup yang baik dan selamat. Akan tetapi mengerjakan kecerdasan emosional dan spiritual tidak cukup dilakukan secara kognitif, sebagaimana mengajarkan kecerdasan intelektual. Dalam hal ini diperlukan proses penerapan dari berbagai teori yang ada ke dalam hati sanubari. Salah satu cara terbaik mengajarkan dunia afektif bagi siswa adalah pemberian teladan dan contoh nyata yang ditampilkan oleh para pemimpin dan orang yang mempunyai pengaruh besar di lingkungan tempat siswa belajar. Menurut Sani dan Kadri (2016:140) yang menyatakan bahwa keteladanan dalam pendidikan, khususnya pendidikan Islam merupakan cara yang paling efektif dan paling baik dalam mempersiapkan anak agar menjadi anak yang berhasil dalam pendidikannya dari segi akhlak, mental, maupun dalam kehidupan sosialnya.

Dengan mengasramakan selama siswa sekolah, siswa tidak hanya mendapatkan pelajaran secara kognitif, melainkan dapat menyaksikan langsung bagaimana perilaku pemimpin, kepala sekolah, pengajar, pelatih dan pengasuh yang bertanggung jawab terhadap perkembangan menuju kedewasaan mereka. Pengasramaan siswa ini merupakan sebuah keuntungan bagi tenaga pengajar untuk memberikan pemahan yang lebih detail dan pelaksanaan dari pemahaman tersebut dalam kegiatan seharihari di sekolah sehingga bisa menjadi suatu pengetahuan yang bisa diaplikasikan untuk bekal kehidupan siswa.

b. Pembiasaan

Salah satu cara seorang pengajar, pelatih dan pengasuh untuk menanamkan sikap disiplin pada siswa SMA Plus Boarding School Astha Hannas adalah menggunakan metode pembiasaan. Budimansyah (2010:63) mengemukakan bahwa dalam rangka menumbuhkan kebiasaan ini mengenalkan istilah habituasi yang menurutnya 
habituasi adalah proses penciptaan aneka situasi dan kondisi (persistent life situation) yang berisi aneka penguatan (reinforcment) yang memungkinkan peserta didik pada satuan pendidikannya, dirumahnya, di lingkungan masyarakatnya membiasakan diri berperilaku sesuai nilai dan menjadikan perangkat nilai yang telah diinternalisasi dan dipersonalisasi melalui proses ulu hati, olah dikir, olah raga, olah rasa, da karsa itu sebagai karakter atau watak.

Metode pembiasaan ini intinya adalah pengalaman-pengalaman yang biasa dikerjakan dalam kesehariannya. Sebagaimana Sauri (2006:51) menyebutkan bahwa metode pembiasaan adalah metode yang berintikan pengalaman, yang dibiasakan adalah berupa pengalaman-pengalaman yang diamalkan. Inti pembiasaan adalah pengulangan.

Proses pembiasaan harus dimulai dan ditanamkan kepada anak sejak dini. Karena potensi ruh keimanan manusia yang diberikan oleh Allāh harus senantiasa dipupuk dan dipelihara dengan memberikan pembiasaan dan pelatihan dalam beribadah. Jika pembiasaan sudah ditanamkan, maka anak tidak akan merasa berat lagi untuk beribadah. Bahkan lebih dari itu, karena sudah dibiasakan untuk melaksanakan ibadah, maka seorang anak ketika tidak melakukan pembiasaan tersebut bisa merasa hampa hidupnya dan tidak tahu arah tujuan hidupnya.

Metode pembiasaan termasuk metode yang mudah untuk dilakukan karena tidak memakan biaya dan juga tidak memakan waktu yang begitu panjang, akan tepai metode ini harus dilakukan setiap hari. Metode ini tergolong metode yang efektif untuk mencapai suatu tujuan pembelajaran. Akan tetapi orang dewasa atau pendidik yang berperan untuk mengawasi siswa harus berusaha terus untuk melakukan pengontrolan kepada siswa agar program pembiasaannya berjalan lancar, tertib dan menjadi bermanfaat.

Lingkungan pertama yang sangat mepengaruhi karaker anak adalah lingkungan keluarga atau orang tuanya. Namun apabila anak di sekolahkan di sekolah yang bersistem boarding school maka sekolah yang akan menjadi lingkungan pertama siswa, oleh karena itu SMA Plus Astha Hannas membuat program pembiasaan yang diprogram untuk menanamkan nilai-nilai keagamaan kepada siswa. Adapun setelah diobservasi dapat diketahui bahwa pembiasaan untuk menanamkan nilai-nilai keagamaan yang diprogramkan di SMA Plus Astha Hannas adalah salat berjamaah, dzikir setelah salat, do’a setelah salat, bersalaman, salat sunah, membaca Al-Qur `ān dan tausyiah. 
c. Pemberian Nasihat

Setiap manusia tidak luput dari kesalahan, begitupun dengan siswa-siswi SMA Plus Astha Hannas yang mana merupakan sosok yang belum dewasa dan masih perlu bimbingan dari orang lain maka perlu adanya metode pemberian nasihat. Nasihat menurut Poerwadarminta (2007:672) dalam KBBI diartikan sebagai ajaran atau pelajaran baik; anjuran (petunjuk peringatan atau teguran) yang baik Sedangkan secara istilah, menurut Latif (2014:105) nasihat adalah perkataan atau ajaran baik seseorang kepada orang lain agar menjadi lebih baik.

Umat Islam memiliki kewajiban saling menasihati antar sesamanya. Hal tersebut perlu agar sama-sama menjadi lebih baik di hadapan Allah swt. perbuatan saling menasihati merupakan salah satu contoh perbuatan baik yang dapat disebut dakwah yang dilakukan oleh seorang muslim terhadap muslim yang lain. Oleh karena itu, umat Islam harus membiasakan diri untuk saling menasihati, baik itu memberi nasihat maupun menerima nasihat. Pemberian nasihat ini tentunya berdasarkan aturan-aturan agama, budaya yang berlaku di sekolah hususnya. Dengan adanya pemberian nasihat ini diharapkan siswa dan siswi SMA Plus Astha Hannas bisa untuk tidak mengulangi kesalahan-kesalahan yang telah dilakukan dan melakukan hal-hal yang baik menurut agama dan budaya, sehingga bisa muncul dari siswa-siswi karakter atau akhlak yang baik sesuai tuntunan agama.

Pemberian nasihat guru kepada muridnya perlu diberikan dengan memberikan alasan, penjelasan, pengarahan, dan diskusi-diskusi. Juga bisa dilakukan dengan teguran, mencari tahu penyebab masalah dan kritikan sehingga tigkah laku anak berubah.

Dalam silabus, materi mengenai saling memberi nasihat ini diajarkan pada materi PAI bab III kelas XII dan didalamnya dicantumkan ayat-ayat Al-Qur`an yang berkenaan dengan nasihatnya yaitu Al-dzariat [51] ayat 55, Al-'Asr [103]: 1-3 dan AlNahl [16]: 125 dan Al-Baqarah[2]: 83).

d. Hukuman dan Hadiah

Dalam menjalankan tugas pendidikan, sekolah dituntut untuk menggunakan metode yang efektif. Salah satu cara agar membentuk akhlak siswa yang baik dapat dilakukan dengan menggunakan metode pemberian hadiah (tawāb) dan hukuman ( $i q \bar{a} b)$. Mujib \& Mudzakkir (2010:206) menyebutkan bahwa metode țawāb dan iqāb adalah metode yang dilakuan dengan cara memberi hadiah/anugerah (țawāb) pada peserta didik yang berprestasi dan hukuman (iqāb) bagi mereka yang melanggar. 
Dari sudut pandang bahasa Inggris, ganjaran disebut juga reward sedangkan punishment adalah hukuman. Metode pemberian ganjaran dan hadiah merupakan dua metode pengajaran yang selalu bersamaan atau saling melengkapi. Dalam pelaksanaan metode țawāb dan'iqā b, pendidik harus bisa bijaksana untuk menyesuaikan dengan psikologis anak atau dengan kata lain harus menimbang hukuman yang cocok untuk diberikan kepada peserta didik dan hadiah yang cocok pula untuk peserta didik.

Hadiah dapat berupa materi seperti alat belajar, makanan, minuman dan lain-lain. Hadiah pun bisa berupa imaterial seperti pujian. Adapun hukuman adalah suatu akibat dari perbuatan yang dilakukan oleh seseorang yang berupa hal tidak menyenangkan atau tidak disukai orang lain yang dibalas dengan sesuatau yang tidak menyenangkan bagi dirinya sendiri.

Ganjaran dan hukuman disamping sebagai alat pendidikan, keduanya pun bisa menjadi suatu alat untuk memotivasi siswa dalam mencapai prestasi belajar siswa yang setinggi-tingginya. Dengan mengunakan metode ganjaran dan hukuman, kegiatan belajar mengajar di SMA Plus Boarding School Astha Hannas menjadi lebih aman, nyaman dan terkendali juga tertib.

e. Hasil Pembinaan Keagamaan

Pembinaan keagamaan yang dilaksanakan di SMA Plus Boarding School Astha Hannas Subang setelah diteliti ternyata menghasilkan nilai-nilai keagamaan siswa yang lebih baik dari sebelumnya. Pembinaan keagamaan yang dilaksanakan di SMA Plus Boarding School Astha Hannas Subang memiliki fungsi penting dalam pengembangan watak dan kepribadian siswa. ia juga berperan dalam pengembangan sistem kehidupan yang sehat sehingga mampu melahirkan generasi yang tumbuh dengan sikap tanggung jawab, disiplin dan kerjasama.

f. Tanggung Jawab

Tanggung jawab merupakan sikap atau perilaku seseorang untuk melaksanakan tugas dan kewajiban sebagaimana yang seharusnya dia lakukan, terhadap diri sendiri, masyarakat, lingkungan (alam, sosial, dan budaya), negara dan Tuhan Yang Maha Esa (Arismantoro, 2008: 29).

Perilaku tanggung jawab siswa SMA Plus Boarding School Astha Hannas Subang setelah mendapatkan pembinaan keagamaan, terdapat perubahan yang lebih baik yang ditunjukan oleh siswa yaitu siswa lebih memiliki sikap tanggung jawab dalam beribadah, namun masih ada beberapa siswa yang melaksanakan ibadah tidak 
sepenuh hati atau malas-malasan dan terkadang masih ada sedikit candaan ketika akan melaksanakan salat.

Selain tanggung jawab dalam beribadah di sekolah, siswa pun mempunyai rasa tanggung jawab lebih baik dari sebelumnya ketika melaksanakan ibadah di rumah, namun berbeda dengan di sekolah yang melaksanakan salat secara berjamaah di Masjid, ketika di rumah siswa teradang salat hanya sendirian dan tidak tepat waktu juga tidak berzikir seperti halnya yang dilakukan ketika di Sekolah.

Begitupun ketika di kelas, rasa tanggung jawab ditunjukkan oleh siswa melalui perilaku siswa yang mengikuti semua pembelajaran dikelas dan tanggung jawab dalam merawat kelas juga mempunyai rasa tanggug jawab dalam mengerjakan tugas dari guru ketika di dalam kelas maupun tugas di luar kelas (PR).

g. Disiplin

Penerapan kebiasaan baik dan kedisiplinan adalah beberapa faktor efektif menentukan bagi tujuan pembinaan nilai-nilai keagamaan. Setelah siswa mendapatkan nilai-nilai pembinaan keagamaan yang diselenggarakan disekolah secara penuh kedisiplinan dan pemantauan yang maksimal, siswa pun mempunyai rasa disiplin tinggi yang dicerminkan oleh periaku siswa yang begitu mudahnya melangkahkan kaki ke Masjid guna melaksankan kegiatan-kegiatan keagamaan di Masjid seperti salat berjama'ah, zikir dan tausyiah.

Selain disiplin dalam mengikuti pembinaan di Masjid, siswa pun disiplin dalam mengikuti pembelajaran di kelas. Hal ini dicerminkan ketika awal masuk kelas siswa tidak ada yang terlambat dan mengikuti pembelajaran sampai dengan selesai, namun ketika setelah salat Żuhur terkadang siswa terlambat masuk kelas kembali untuk mengikuti pembelajaran dengan alasan ke kamar mandi untuk membersihkan badan atau buang air besar.

Selain disiplin dalam melaksanakan kegiatan keagamaan di Masjid dan di kelas, siswa pun mempunyai rasa disiplin dalam mematuhi peraturan kehidupan siswa yang sudah dibuat oleh sekolah, seperti kembali ke sekolah setelah izin bermalam tepat waktu dan tidur juga bangun sesuai jadwal yang ditentukan.

Yang perlu diperbaiki dalam penanaman disiplin ini adalah sikap tenaga pengajar dan pelatih yang kurang disiplin ketika masuk kelas dan pelaksanaan upacara hari senin. 
h. Kerjasama

Menurut Soekanto (2006: 66) kerjasama merupakan suatu usaha bersama orang perorangan atau kelompok untuk mencapai tujuan tertentu. Ayat Al-Qur 'ān tentang kerjasama tertulis pada surah kedua yaitu Al-Mā'idaђ ayat 9 yang artinya” tolongmenolonglah kamu dalam kebajikan dan taqwa dan jangan tolong menolong dalam berbuat dosa dan pelanggaran..”

Perilaku kerjasama siswa SMA Plus Boarding School Astha Hannas setelah mendapatkan pembinaan keagamaan yang baik, hasilnya muncul pada diri siswa sikap semangat untuk mengamalkan nilai-nilai keagaman di sekolah. Hal ini dicerminkan dalam kegiatan siswa yang bekerjasama ketika membersihkan Masjid pada hari jum'at pagi bersama pengasuh sebelum jam kegiatan belajar mengajar dan sebelum melaksanakan serta setelah melaksanakan salat jum'at.

Perilaku kerjasama lain yang dilakukan oleh siswa adalah bekerjasama dalam merawat atau membersihkan setiap hari barak tempat siswa istirahat sesuai jadwal yang telah ditentukan bersama pengisi barak.

Selain bekerjasama dalam merawat dan menjaga kebersihan sekolah, dengan pembinaan keagamaan pula siswa mempunyai kerjasama yang baik dalam hal membantu teman. Hal ini tercermin dalam sikap siswa yang bekerjasama dengan teman lainnya untuk membantu siswa yang sakit seperti mengambil makanan untuk teman yang sakit di mensa atau tempat makan dan mengantar siswa yang sakit ke klinik sekolah.

Kerjasama lain yang dilakukan siswa adalah bekerjasama di dalam kelas ketika diberi tugas kelompok oleh guru. Dalam pemaparan materi Al-Qur'ān surah Ali imran ayat 190, 191 dan 159 tentang berpikir kritis dan demokratis guru Pendidikan Agama Islam membagi siswa menjadi beberapa kelompok dan guru memberikan pengarahan kepada siswa untuk memberi memberi tahu teman yang belum bisa tajwid dari ayat tersebut. Hasilnya dengan bekerja kelompok dalam membahas suatu materi siswa mempunyai rasa kerjasama dalam memecahkan masalah di kelas.

i. Cinta Tanah Air

Cinta tanah air dipadankan dengan nasionalisme dan patriotisme. Nasionalisme adalah suatu keyakinan yang dianut oleh individu maupun sejumlah besar manusia, sehingga mereka membentuk suatu kebangsaan yang terorganisir dalam suatu wilayah pemerintaha; nasionalisme adalah rasa kebersamaam sebagai suatu bangsa (Octavia dkk, 2014:27) 
Cinta tanah air tercermin dalam sejarah para Nabi dan Rasul, salah satunya dalam firman Allah swt yang artinya:

"Dan (ingatlah), ketika Ibrahim berdoa: "Ya Tuhanku, Jadikanlah negeri ini, negeri yang aman sentosa, dan berikanlah rezki dari buah-buahan kepada penduduknya yang beriman diantara mereka kepada Allah dan hari kemudian. Allah berfirman: "Dan kepada orang yang kafirpun aku beri kesenangan sementara, kemudian aku paksa ia menjalani siksa neraka dan Itulah seburukburuk tempat kembali".(Q.S Al-Baqarah [2]:126)

Cinta tanah air dalam bahasa Arab disebut al-wathaniyyah (kebangsaan) atau hubb al-wathan (nasionalisme). Pecinta nusa bangsa disebut nasionalis (Poerwadarminta, 2007:27).

Jika seseorang mencintai tanah airnya, ia akan senang jika tanah air tersebut dalam kondisi baik disemua dimensi: sosial, ekonomi, agama, geografis dan sebagainya. Sebaliknya, ia akan prihatin jika tanah airnya dalam kondisi mengenaskan, misalnya tercemar tanah, air dan udaranya, atau terjajah ekonomi dan teritorinya. Selain itu pecinta tanah air akan mengekpresikannya melalui tindakan nyata, misalnya menjaga alam eksploitasi, pencemaran dan perusakan, atau turut berupaya memperbaiki kondisi sosial ekonomi tanah airnya. Lebih jauh lagi, ia rela mengorbankan harta-benda dan jiwa-raganya untuk kemajuan Tanah Airnya dan membelanya sampai titik darah penghabisan.

Di SMA Plus boarding School Astha Hannas setelah siswa mendapatkan pembinaan keagamaan terdapat perubahan yang baik. Perilaku cinta tanah air yang dimiliki siswa tercermin dalam perilaku siswa yang semangat mengerjkan upacara tiap hari senin. Dalam pelaksanaan upacara pun siswa berbaris dan berpakaian secara rapih dan beratribut lengkap bagi petugas upacara. Namun masih ada beberapa siswa yang belum bisa melaksanakan upacara tidak tertib dan beberapa pengajar yang tidak mengikuti pelaksanaan upacara.

j. Toleransi

Kata toleransi berasal dari bahasa Inggris tolerance, yang diserap dari bahasa latin tolerantia, berarti kesabaran atau ketahanan terhadap sesuatu. Dalam Kamus Besar Bahasa Indonesia toleransi dimaknai sebagai sifat atau sikap menenggang (menghargai, membiarkan, membolehkan) pendirian (pendapat, pandangan, kepercayaan, kebiasaan, kelakuan dan sebagainya) yang berbeda atau bertentangan dengan pendirian sendiri, dalam bahasa Arab toleransi diistilahkan sebagai tasāmuh (Poerwadarminta , 2007:1084). 
Sikap toleran ditunjukan dengan memberi kemudahan pada pihak yang berbeda untuk melakukan apa yang diyakininya dan memperlakukan dengan kelembutan dan kasih sayang terlepas apapun pendiriannya, sehingga orang yang toleran akan bersikap menghargai orang lain yang berbeda paham dengannya sebagaimana Octavia dkk (2014:85) meyebutkan bahwa seseorang dikatakan toleran jika ia menghargai orang lain dan dapat merima perbedaan. Ia tidak merasa benar sendiri atau pun memaksakan pandangan dan keyakinannya terhadap pihak lain. Sikap toleran bukan berarti membenarkan pandangan atau keyakinan yang berbeda, akan tetapi mengakui hak dan kebebasan orang lain untuk memiliki dan mengekspresikannya dan orang yang intoleran adalah mereka yang menghalanghalangi juga mempersulit pihak lain mengekspresikan dan menjalankan keyakinannya atau bahkan bersikap kasar serta melancarkan kekerasan fisik terhadap pihak yang berbeda dengannya.

Bangsa Indonesia terdiri dari berbagai macam suku, bahasa, budaya, etnis, dan agama. Begitupun di SMA Plus Boarding School Astha Hannas, keadaan siswa yang mengenyam pendidikan di sekolah ini berasal dari berbagai daerah di Indonesia seperti Subang, Indramayu, Cirebon, Papua, Sumatera, Palembang, Kalimantan dan Bangka. Begitu juga dengan bahasa daerah tentunya berbeda. Selain itu agama siswa SMA Plus Boarding School Astha Hannas pun berbeda. Namun beragam perbedaan tersebut tidak menjadikan siswa untuk bersatu padu menjalin persatuan dan kesatuan di SMA Plus Boarding School Astha Hannas.

Setelah siswa mendapatkan pembinaan keagamaan, terdapat perilaku toleransi yang berbeda dengan sebelumnya. Perbedaan toleransi yang dimiliki siswa ini tercermin dalam perilaku siswa yang tidak ada kesenjangan ketika di kelas seperti duduk dengan yang berbeda agama, suku dan daerah. Ketika waktunya ibadah pun, siswa saling mengingatkan kepada yang berbeda agama untuk melaksanakan ibadah sehingga dengan diingatkan oleh yang berbeda agama siswa merasa malu apabila bermalas-malasan atau tidak melaksanakan ibadah.

\section{Kesimpulan}

Berdasarkan hasil penelitian dan pembahasan pada bab sebelumnya, maka diperoleh kesimpulan umum bahwa pola pembinaan keagamaan siswa SMA Plus Boarding School Astha Hannas diinternalisasikan pada tiga strategi pendidikannya, yaitu: pengajaran, pelatihan dan pengasuhan (tri tunggal) yang mana pada pelaksanaannya sebagai berikut: 
a. Pembinaan kegamaan melalui pengajaran dilakukan melalui dua cara, yaitu: pertama, melalui pembelajaran PAI (secara umum) yang mengacu pada kurikulum Diknas (kurikulum 2013) yang diterapkan pada kelas X, XI dan XII sebagai syarat memenuhi nilai ijazah. Kedua, melalui sistem yang diberakukan di sekolah pada semua mata pelajaran, yaitu: membaca do'a sebelum dan sesudah belajar serta diwajibkan untuk melaksanakan salat tepat waktu sekalipun bukan jadwal PAI.

b. Pembinaan kegamaan melalui pelatihan dilakukan melalui cara, yaitu: pertama, membaca do'a ketika akan memulai dan setelah latihan bahasa, olahraga, seni budaya dan pramuka. Kedua, pelaksanaan pelatihan bahasa bertempat di Masjid An-Nās. Ketiga, tidak menghususkan pelatihan bagi pemeluk agama tertentu atau hanya untuk suku tertentu.

c. Pembinaan keagamaan melalui pengasuhan dilakukan melalui cara, yaitu: pertama, melaksanakan salat lima waktu tepat waktu di masjid An-Nās. Kedua, membiasakan berẓikir dan berdo’a setiap setelah melaksanakan salat lima waktu. Ketiga, membaca ayat suci Al-Qur`ān. Keempat, latihan tausyiah oleh tiap-tiap siswa. Kelima, mengadakan salat jumat bersama di masjid sekolah. Keanam, melaksanakan upacara tiap hari senin yang di dalam upacara tersebut ada pembacaan do'a. Ketujuh, memperingati hari-hari besar Islam dengan acara-acara yang mengandung nilai-nilai agama.

\section{Saran}

Untuk menunjang ketercapaian pembinaan keagamaan di SMA Plus Boarding School Astha Hannas maka pengajar, pelatih dan pengsuh menggunakan metode keteladanan, pembiasaan, nasihat, hukuman dan hadiah.

Adapun yang menjadi hambatan internal serta eksternal menjadi kendala yang dihadapi dalam pelaksanaan pembinaan keagamaan siswa pada SMA Plus Boarding School Astha Hannas di antaranya:

a. Sebagian orang tua belum memahami tentang esensi pendidikan boarding school, sehingga orang tua protes terhadap kebijakan-kebijakan sekolah dan mempunyai rasa khawatir berlebih.

b. Kurangnya monitoring dari kepala sekolah,

c. Beberapa tenaga pendidik dan kependidikan kurang perhatian terhadap pembinaan agama siswa,

d. Perbedaan suku dan agama siswa yang berbeda. 
Sedangkan faktor-faktor yang menjadi pendukung pelaksanaan pembinaan kegamaan siswa diantaranya:

a. Kebijakan sekolah yang mendukung penuh terhadap kegiatan-kegiatan kegamaan

b. Adanya pengajar atau pelatih yang memantau aktivitas siswa selama 24 jam

c. Adanya sarana dan prasarana yang menunjang untuk tercapainya proses pembinaan kegamaan siswa.

Pembinaan keagamaan di SMA Plus Boarding School Astha Hannas ini membuahkan hasil yang positif yang dicerminkan oleh siswa dalam sikap:

a. Tanggung jawab

Perilaku tanggung jawab siswa SMA Plus Boarding School Astha Hannas setelah mendapatkan pembinaan keagamaan secara umum sudah cukup baik. Siswa sudah dapat bertanggung jawab dalam melaksanakan ibadah.

b. Disiplin

Perilaku disiplin siswa SMA Plus Boarding School Astha Hannas setelah mendapatkan pembinaan keagamaan secara umum sudah cukup baik meskipun terkadang terdapat siswa yang masih malas dalam melaksanakan salat berjama'ah dan pembiasaan keagamaan.

c. Kerjasama

Perilaku kerjasama siswa SMA Plus Boarding School Astha Hannas setelah mendapatkan pembinaan keagamaan secara umum sudah cukup baik yang tercermin dalam kebiasaan siswa yang membersihkan dan merawat kelas, masjid, barak dan halaman secara bersama-sama juga membantu teman yang sedang sakit.

d. Cinta tanah air

Perilaku cinta tanah air siswa SMA Plus Boarding School Astha Hannas setelah mendapatkan pembinaan keagamaan secara umum sudah cukup baik yang tercermin dalam kebiasaan siswa yang mengikuti upacara bendera hari senin dan hari peringatan nasional lain dan belajar di sekolah secara semangat dan antusias.

e. Toleransi

Perilaku toleransi siswa SMA Plus Boarding School Astha Hannas setelah mendapatkan pembinaan keagamaan secara umum sudah cukup baik yang tercermin dalam kebiasaan siswa yang saling mengingatkan teman yang berbeda agama untuk beribadah dan bergaul dengan teman yang berbeda agama tidak dibatasi. 


\section{Daftar Pustaka}

Arismantoro. (2008). Tinjauan Berbagai Aspek Character Building . Jakarta: Tiara Wacana.

Asyafah, A. (2014, February 15). The Method of Tadabur Qur`an : What Are the Student Views? International Education Studies, VII, 98-105.

Asyafah, A. (2016). Model Islamic Full Day School. Dalam A. S. dkk (Penyunt.), The 1st UPI International Conference on Islamic Education (hal. 39-48). Bandung: Alqaprint.

Djalaluddin. (2002). Psikologi Agama . Jakarta: PT. Raja Grafindo Persada.

Hasan, H. I. (1998). Filsafat Pendidikan Islam. Jakarta : CV Pustaka Setia.

Kadri, R. A. (2016). Pendidikan Karakter Mengembangkan Karakter Anak yang Islami. Jakarta: Bumi Aksara.

Kosasih, A. (2016). Pendidikan Karakter Religius Melalui Pembiasaan Dzikir. Prosiding The 1st UPI International Conference on Islamic Education, 58-59.

Latif, M. (2014). Pendidikan Agama Islam dan Budi Pekerti untuk SMA/MA/SMK/MAK Kelas XII. Jakarta: CV Graha Pustaka.

Maksudin. (2006). Pendidikan Nilai Sistem Boarding School di SMP IT Abu Bakar Hasil Penelitian Untuk Disertasi . Yogyakarta : Program Pasca Sarjana UIN Sunan Kalijaga.

Mudzakkir, A. M. (2010). Ilmu Pendidikan Islam . Jakarta : Kencana.

Muhaimin. (2009). Rekonstruksi Pendidikan Islam. Jakarta: PT. Raja Grafindo Persada.

Octavia, L dkk (2014). Kumpulan Bahan Ajar Pendidikan Karakter Berbasis Tradisi Pesantren. Jakarta: Rumah Kitab.

Poerwadarminta, W. (2007). Kamus Bahasa Indonesia. Jakarta: Balai Pustaka.

Samani, M dan Hariyanto (2016). Pendidikan Karakter. Bandung: PT Remaja Rosdakarya.

Sauri, S. (2006). Membangun Komunikasi dalam Keluarga. Bandung: PT Genesindo. Syahidin. (2009). Moral dan Kognisi Islam . Bandung : CV. Alfabeta.

Syaodih, N. (2010). Metode Penelitian Pendidikan. Bandung: PT Remaja Rosdakarya. Ulfiani, T. (2012). Peran Boarding School Pada SMP IT Abu Bakar Yogyakarta Sebagai Salah satu Upaya Penerapan Pendidikan Karakter . Yogyakarta: Universitas Negri Yogyakarta.

Zuriah, N. (2006). Metodologi Penelitian Sosial dan Pendidikan. Jakarta: PT. Bumi Aksara. 